Gerald P. Dwyer, Jr. and $R$. Alton Gilbert

Gerald P. Dwyer, Jr., a professor of economics at Clemson University, is a visiting scholar and $R$. Alton Gibert is an assistant vice president at the Federal Reserve Bank of St. Louis. Erik A. Hess and Kevin L. Kliesen provided research assistance.

\title{
Bank Runs and Private Remedies
}

URRENT banking regulation in the United States is based in part on the notion that both the banking system and the economy must be protected from the adverse effects of bank runs. An example often cited as typical is the string of bank runs from 1930 to 1933, which conventional wisdom holds responsible for thousands of bank failures and the Banking Holiday of 1933 when all banks closed. The runs on savings associations in Ohio and Mary. land in 1985 are more recent examples.

This conventional view is reflected in a recent comment on the "Panic of 1907 " in the Wall Street Journal (1989):

Long lines of depositors outside the closed doors of their banks signaled yet another financial crisis, an all-too familiar event around the turn of the century.

Research in the last few years on bank runs indicates that the conventional view is mistaken. Runs on the banking system were not commonplace events, and their impact on depositors and the economy easily can be overstated. Prior to the formation of the Federal Reserve System in 1914 , banks responded to runs in ways that lessened their impact. These private remedies did not solve the problem of runs, but they did mitigate the effects of the runs on the banks and the economy. In this article, we explain the private remedies for runs and provide some evidence on the frequency and severity of runs on the banking system.

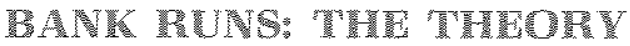

Before examining the history of bank runs, it is useful to consider why banks are vulnerable to runs. This examination establishes a framework for determining the kinds of observations that would be consistent with their occurrence.

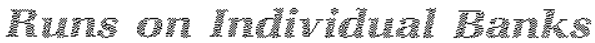

In a run, depositors attempt to withdraw currency from a bank because they think the bank will not continue to honor its commitment to pay on demand a dollar of currency for a dollar of deposits. ${ }^{3}$ One aspect of the contract banks make with their customers is central to understanding why depositors would run on their bank. Banks make contractual promises that they cannot always honor: exchange of gold or 
currency at par value for bank liabilities. ${ }^{2}$ When banks issued notes as a form of currency, the promise was a contractual agreement to deliver specie (gold or silver) in exchange for the bank's notes at par value. Banks currently promise to deliver U.S. currency to depositors on demand at par value. Because banks hold reserves that are only a fraction of their liabilities payable on demand, they cannot honor this promise if all of their depositors try to convert deposits into currency at the same time.

Fractional-reserve banking by itself is not sufficient to make it impossible for banks to honor their promises to deliver currency in exchange for deposits on demand. Banks always could honor a promise to pay currency at a variable exchange rate of currency for deposits. If all depositors want to exchange their deposits for currency at the same time banks do not have sufficient currency (or other reserves that can be transformed into currency on a dollar-fordollar basis instantaneously) to meet that demand for currency at a price of one dollar of currency for one dollar of deposits. ${ }^{3}$

In the normal course of affairs, the inability of all depositors to exchange their deposits for currency is irrelevant. As some depositors withdraw currency from a bank, others deposit it. The low probability of every depositor closing his or her account at the same time is the reason a bank usually can operate with fractional reserves and pay currency on a dollarfor-dollar basis.

A low probability is not the same as a zero probability though. Information or rumors which suggest a capital loss by a bank may induce its depositors to attempt to convert their deposits to currency. ${ }^{4}$ The mere expectation that other depositors will attempt the same conversion also can cause a run on a bank. A run on a single bank is unlikely, however, to have substantial effects on the economy. The primary effect of a single bank closing is that the bank winds up its affairs and no longer operates.
The effects of a run by depositors on one bank can be illustrated by an example. Table 1 shows the balance sheet of a hypothetical national bank in New York City in the national banking period (1863 to 1914). Its liabilities include deposits and national bank notes backed by securities deposited with the Treasury. In the event of the bank's failure, the notes were guaranteed by the U.S. Treasury, whether or not the deposited bonds were sufficient backing for the notes. Apparently as a result of this guarantee, runs on banks in the national banking era were runs by depositors, not by note holders. ${ }^{\text {* }}$

During this period, national banks in New York City were required to maintain reserves of specie and legal tender equal to 25 percent or more of deposits, with the required ratio of reserves to deposits lower for national banks in other cities. Banks generally held excess reserves as a buffer stock to meet deposit withdrawals, but we use a reserve ratio of 25 per. cent to keep the numerical example simple. The second part of table 1 shows the initial loss of reserves upon withdrawal of $\$ 2$ million of deposits, while the last part indicates the reaction of the bank to the decrease in deposits. An individual bank can replenish its reserves by selling assets; in the example, the bank returns its reserve ratio to 25 percent by selling $\$ 1.5$ million in assets. At least part of the reserves are from other banks, thereby transmitting the reserve loss to other banks.

In a run on a single bank, the specie and legal tender withdrawn from the bank are likely to be largely deposited in other banks. As a result, a run on a single bank is not likely to drain reserves from the banking system or increase currency held by the public. If the currency withdrawn is deposited in other banks, the net effect on the bank's balance sheet is that shown in table 1 , and the deposit and reserve loss at this bank is matched by a similar increase in deposits and reserves at other banks.
2Whether this promise is a result of market forces or government regulation is an open question. Davis (1910) summarizes the laws in the United States in the 19th century, and Schweikart (1987) provides the historical development of these laws in the South in the 19th century.

3Promises that cannot be kept in all states of the world are hardly unique to banking. For instance, tirms often cannot make payments on debt if there is a large decrease in the demand for their products. The common legal word for failure to honor contractual commitments is "default."
While default generally is not the expected outcome of a contract, if does happen.

4Among others, Diamond and Dybvig (1983) and Gorton (1985a) present models of runs.

In banking panics prior to the national banking era, customers of banks attempted to redeem their bank notes for specte. For details on the backing for notes in the national banking era, see Friedman and Schwartz (1963), pp. 20-23, 781-82. 
Table 1

\section{Balance Sheet of a National Bank in New York City with a Large Withdrawal of Deposits (millions of dollars)}

NITTAL BALANGE SHEET:

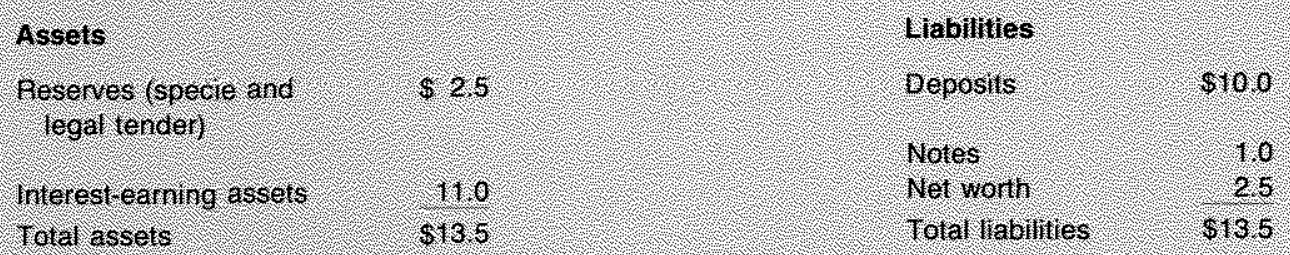

IMMEDIATEL Y AFTER WIHDRAWAL OF $\$ 2$ MLUON BY DEPOSTTORS

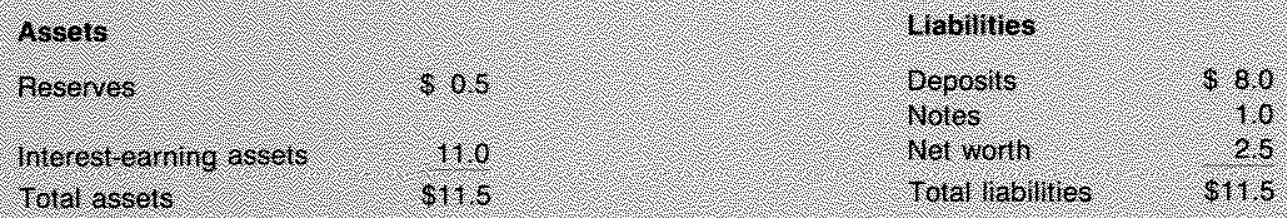

AFTER FESTORATION OF RESERVE RATIO 1025 PERCENT

\begin{tabular}{|c|c|c|c|}
\hline Assats & & Liabilities & \\
\hline Reserves & S 20 & $\begin{array}{l}\text { Deposits } \\
\text { Notes }\end{array}$ & $\begin{array}{r}8.0 \\
1.0\end{array}$ \\
\hline Interest-eaming assefs & 9.5 & Net worth & 2.5 \\
\hline Total assets: & 5115 & Total liabinties & $8+1.5$ \\
\hline
\end{tabular}

\section{Purs on the Banking Syeterts}

Runs on a single bank can develop into runs on the banking system. ${ }^{6}$ An important, if seemingly obvious, aspect of banking is that the likelihood of a bank's default on its deposit agreement is not known with certainty by depositors. Instead, depositors estimate this likelihood as best they can with available information. One type of information that can be useful in estimating the value of a bank's assets is information on the value of assets at other banks. News about the failure of one bank can cause depositors at other banks to raise their estimate of the probability that their bank will default. Contagious bank runs can be defined as runs which spread from one bank or group of banks to other banks.

A term sometimes used for a period of a run on the banking system is a "banking panic," a term that has a connotation of unreasoning fear or hysteria. Contagious runs, however, can be based on the optimal use of all information by all agents. As a simple example, suppose that two banks are identical in all respects known by depositors, and one of the two fails because of loan losses. Because of the first falure, depositors will increase their estimate of the probability that the second bank will fail. If this estimate increases sufficiently, depositors will run on the second bank, even though no other information has appeared. This use of information is quite consistent with rational behavior. Depositors use the information available, and one part of that information is the condition of other banks.

Simultaneous runs on many banks need not be contagious runs though. For example, an exogenous event can increase simultaneously de-

${ }^{6}$ Gorton (1985a) and Waido (1985) provide models of

aspects of the process which we discuss in this section. 


\section{Table 2}

\section{Balance Sheet of the Banking System with a Large Withdrawal of Deposits (millions of dollars)}

\section{Assets}

Reserves

Hiterestearing assets

Total assets
\$ 250

1,100

$\$ 1,350$
Liabilites

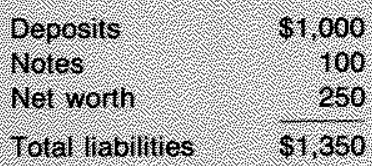

After witharaval or $\$ 200$ millon by depositars

4556

peserves

hierestearning assels

1 olar assets
9. 50

5. 500
Llabintes

Coposis:

Nores

Net worth

Told lablities
8. 200

100

250

6. 550 positors' estimated probability that many banks will fail to redeem at par. Myers (1931) suggests that bank runs in 1914 resulted from the public's expectation that the war would result in a restriction of convertibility of notes and deposits into specie. ${ }^{7}$

Whether a contagious or a simultaneous run, a run on the banking system is associated with a drain of reserves from the banking system. The effect of this withdrawal of reserves is shown in table 2, which illustrates the effect of a $\$ 200$ million increase in the demand for currency. For each bank individually, the initial impact is a withdrawal of reserves. Banks no longer have a reserve ratio of 25 percent, and, as a result, they attempt to increase their holdings of reserves by selling assets. The sale of assets by one bank drains reserves from other banks though, and these banks then sell some of their assets to acquire reserves. Unlike the previous example, the $\$ 200$ million of reserves is gone from the banking system. As table 2 shows, the result of this process is a contraction of deposits and assets that is a multiple of the initial decrease in reserves.

If banks sell relatively large amounts of their assets quickly in a run, they can drive down the market value of their assets and drive up market interest rates. Table 2 could be modified to reflect this effect, with an additional decline in the value of bank assets and their net worth. If the declines in net worth are large enough, the response of the banks to the run indicated in table 2 will cause some banks to fail. Thus, an additional effect of a bank run might be a rise in the rate of bank failure.

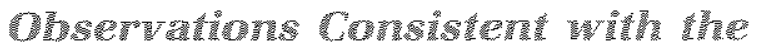 Gccurrerice of Thers}

The definition of a run is based on depositors' estimated probability of non-par redemption by banks. While it is possible to use an economic model to estimate this probability, we use a lessdemanding basis to examine data for evidence

'See Myers (1931), p. 421. Empirically distinguishing between contagious runs and simultaneous runs is a tricky issue, which requires distinguishing between bank runs due to information that aftects bank' assets and those due to information about some banks' assets. One way of

doing this is to define contagious bank runs as those that would not have occurred without runs on earlier banks. There is at least one successful attempt at providing detalled evidence of a contagious run: Wicker's (1980) analysis of the runs in November and December 1930 . 
of runs: we examine the data for consequences of runs. ${ }^{8}$

A leading example of an event consistent with a run on the banking system is a joint restriction of convertibility by banks. Without an official central bank, banks can limit the effects of a run by jointly agreeing to restrict currency payments to depositors. ${ }^{9}$ The effects of such a restriction can be illustrated by referring to table 2. Suppose that, after depositors withdraw $\$ 50$ million in currency, the banks agree to stop making currency payments. In this illustration, deposits decline by only $\$ 200$ million, to $\$ 800$ million. The demand for more currency by depositors will not cause a further decline in deposits because some or all of that demand is refused by the banks.

Hence, one observation that provides clear evidence of a run on a banking system is a restriction of currency payments by banks in the system. An individual bank resorts to a restriction of currency payments if it cannot meet its commitment to pay currency to depositors on demand. Banks will resort to this action jointly if they face a common problem of cur. rency withdrawals.

If the restriction of payments results in significant restrictions on depositors' ability to transform deposits into currency, a market for transforming currency into deposits may develop. If there is such a market, there will be a premium for currency in terms of deposits. ${ }^{10}$

A bank run need not result in restriction though. The following developments also would be consistent with the occurrence of a run on a banking system, although they are not inevitable effects of runs and they can occur in the

BGorton (1988) does estimate a particular model for runs and finds them generally consistent with our analysis. He also defines runs on the banking system, or in his terms "banking panics," as periods when convertibility was restricted in New York City, clearing house loan cer" tificates were authorized by the New York Clearing House or both (1988, pp. 222-23). We prefer not to identify periods with runs based on a single criteria. If we were to pick a single criteria, it would be restriction of payments by banks. With any penalties on nonpar payments, banks will not do this unless they at least believe that they cannot continue payments at par indefinitely. For the use of a multiple set of criteria along our lines, see Bordo (1986).

9The names "restriction of cash payments" or "festriction of convertibility of deposits into currency" are suggested by Friedman and Schwartz (1963, p. 110, in. 32) rather than the traditional name of "suspension of currency payments." Following this suggestion avoids confusion of "suspension of currency payments" with "suspension of operations" and is more consistent with the fact that absence of a run. Perhaps most importantly for our purposes, these indicators of runs can be lessened by a restriction of payments to depositors. They are:

1. a decline in the ratio of reserves to deposits. 2. a rise in the ratio of currency to deposits.

3. for a given monetary base, a decline in the money supply (because the decline in deposits is a multiple of the decline in bank reserves).

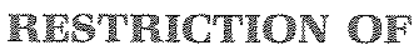

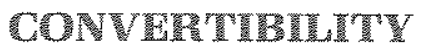

The view that the banking system is vulnerable to runs may be based primarily on the experience of the early $1930 \mathrm{~s}$, but the most relevant period to examine for evidence of runs is before the operation of the Federal Reserve System. Prior to late 1914, the United States had no official central bank..1 We focus on the banking system beginning with the 1850s. While events in earlier years also are of interest, 1853 marks the beginning of a weekly data set on reserves and deposits in banks in New York City which is very useful. In addition, by the 1850 s, New York City was the most important financial center in the United States. Many banks in other parts of the country held correspondent balances in New York City banks, and pressures affecting banks in the rest of the country affected New York City banks through these balances. ${ }^{12}$

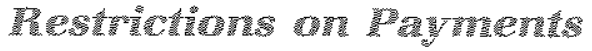

As table 3 indicates, banks in New York City restricted payments on five occasions

banks commonly did not completely stop converting deposits into currency. Currency payments were non-price rationed, not suspended. Evidence for the post-Civil-War period that payments generally were restricted, not suspended, is presented by Sprague (1910), pp. 63-65, $121-24,171-78,286 m 90$, and Andrew (1908), pp. 501\%02.

A more general and precise, but also quite pedantic, name for restrictions would be "restriction of convertibility at par of bank liabilities with promised par redemption on demand."

${ }^{10}$ As we show below, banks remained open for deposits. Hence, a discount on currency could not persist.

11 Friedman and Schwartz (1963) and, in more detail, Timberlake (1978) discuss the central banking activities by the Treasury in the national banking period. As argued forcefully by Dewald (1972), the New York Clearing House acted as a central bank at times.

12 See Myers (1931) and Sprague (1910). 


\section{Table 3}

Dates of General Restriction of Payments in New York City, 1857 to 1933

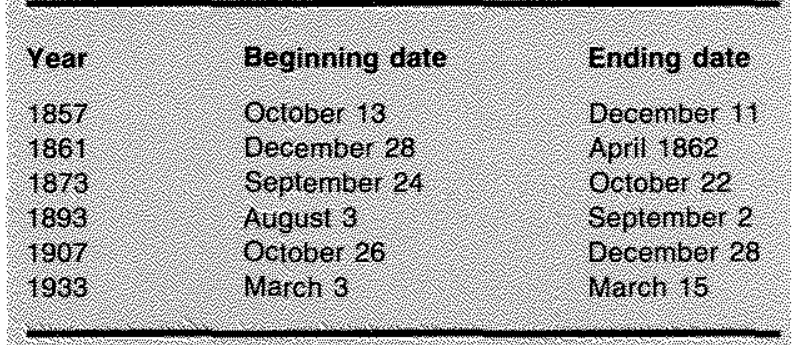

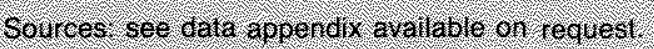

between the 1850 s and $1914 .^{13}$ In the episodes from 1857 to 1907 , banks across much of the country restricted currency payments, but the restrictions were not universal. ${ }^{14}$ The last such restriction was the banking holiday of March 1933. In the banking holiday of 1933, the federal government closed all banks in the country and gradually reopened those that regulators judged to be in satisfactory financial condition. In the earlier restrictions, in contrast, banks remained open and processed transfers of deposits for their customers.

Other than for the restriction of payments in 1907 , it is difficult to obtain precise estimates of how widespread or binding these restrictions were. Shortly after the panic of 1907, A. Piatt Andrew surveyed banks in 147 cities in the United States with populations greater than 25,000. Andrew (1908) found that, of the 145 cities for which he had responses, 53 had no restriction of payments or emergency response. of the remaining 92 , the only restriction of payments in 20 cities was a request by the banks that larger depositors mark their checks as "payable only through the clearing house." In the remaining 72 cities, limits on withdrawals were often discretionary. Even in the 36 cities where there was joint agreement between the banks in the city to limit withdrawals, there was substantial variations across them. For ex-

$13 \mathrm{~A}$ data appendix, available on request from the authors, gives the sources of these dates and the other data in this paper.

${ }^{14}$ For a discussion of 1873 and 1893 , see Sprague (1910), pp. $63-74,168-69$. Andrew (1908) presents the results of a survey for 1907 . ample, in Atlanta, depositors could withdraw up to $\$ 50$ per day and $\$ 100$ per week from their banks. At the same time, depositors in two of these 36 cities, South Bend, Indiana, and Youngstown, Ohio, could withdraw nothing from their checking accounts.

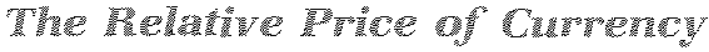 and Deposid}

During the periods of restrictions of currency payments in the national banking era, markets developed in New York City for the exchange of currency for certified checks. Holders of certified checks marked "payable through the clearing house" could obtain currency in this market if they were willing to accept less than the face amount of the certified checks. Figure 1 shows the premiums on currency quoted in these markets in the three periods of restrictions in New York City in the national banking era. These markets operated for about four months in this period. The maximum premiums on currency are about 4 percent to 5 percent, but for most of the days in which these mar. kets operated, the premiums are much smaller. Nonetheless, the important issue is whether the premiums are nonzero, which they are.

\section{Clearinghouses and Festriction}

During these restrictions of payments, banks remained open for much of their regular business and processed checks for their customers as they usually did. In some parts of the country, banks in a local area processed checks bilaterally, but in other areas, banks used clearinghouses to process checks. From 1857 to 1914, these clearinghouses developed an emergency currency used during restrictions for clearing checks.

Clearinghouses for banks - In the second half of the nineteenth century, banks in many cities established clearinghouses to decrease the resources used in clearing checks and exchanging gold and currency with other banks. ${ }^{15}$ Rather than sending checks received to the offices of each bank for collection, members of a clearinghouse sent checks drawn on other member banks to the clearinghouse. Those with net

15Descriptions of clearinghouses are provided by Cannon (1910), Myers (1931), pp. 94-97, and Redlich (1968), ch. XVII 
Figure 1

Currency Premiums during Restrictions of

Currency Payments

September and October 1873

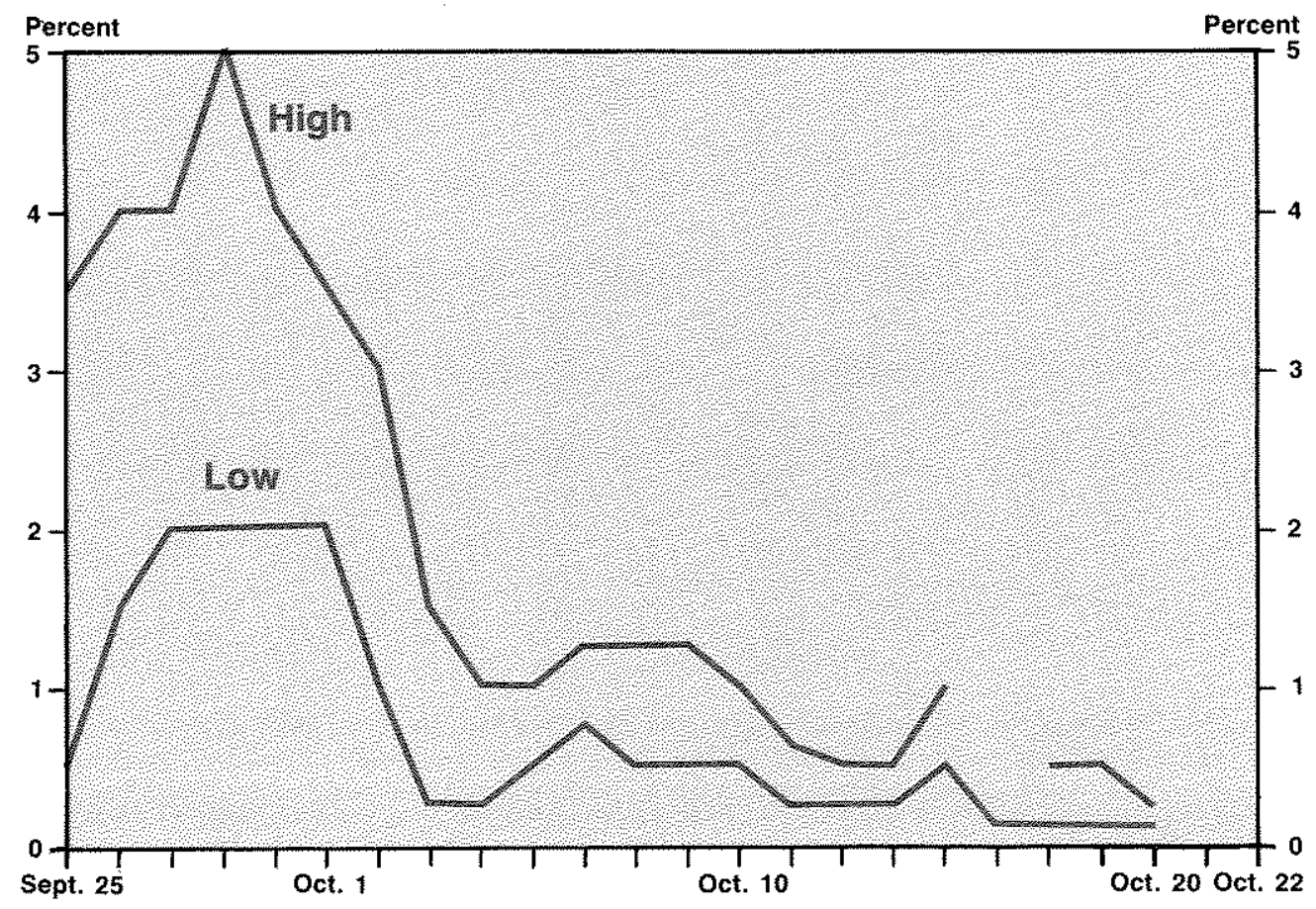

September and October 1893

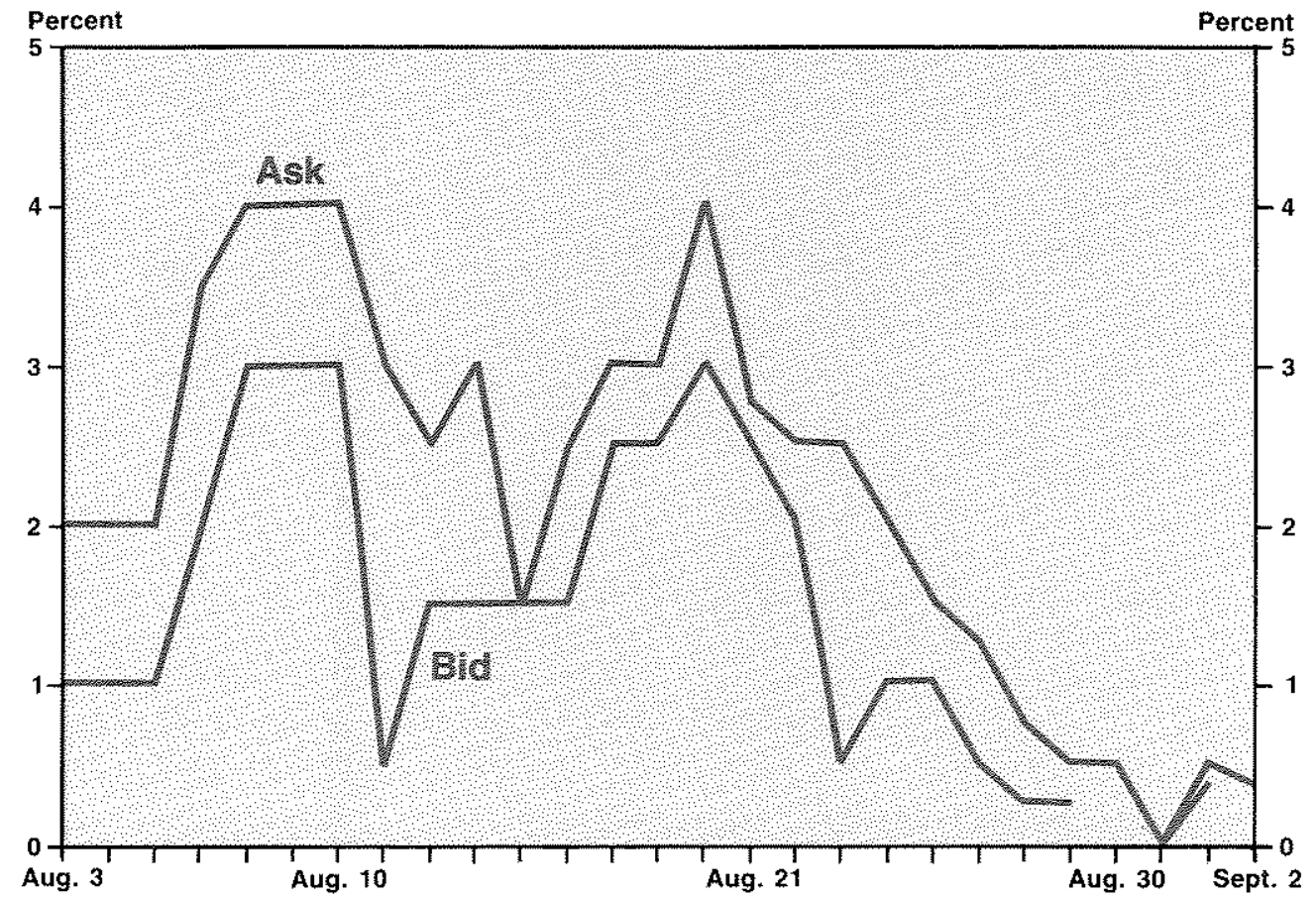




\section{November and December 1907}

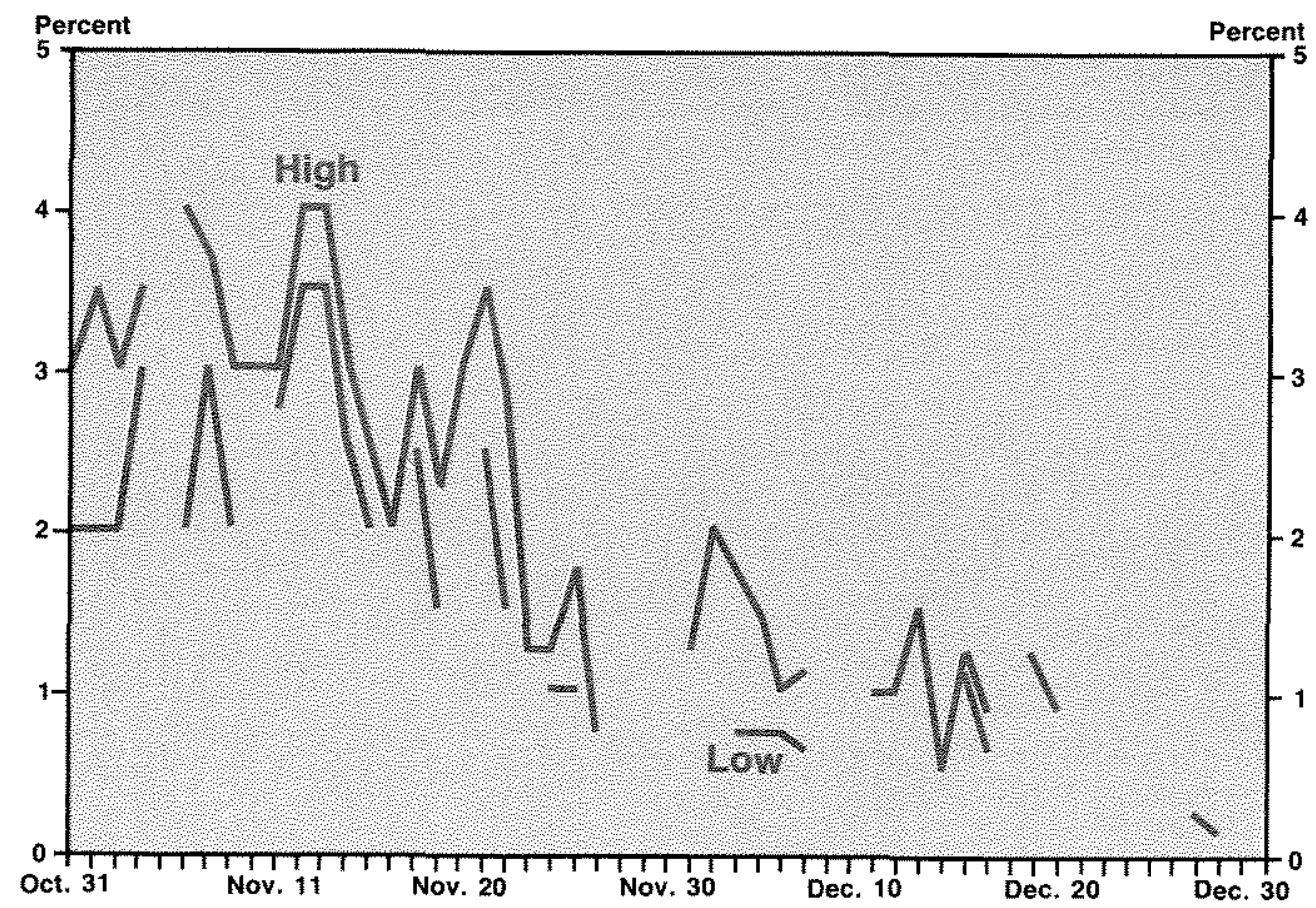

outflows of deposits at the clearinghouse paid those with net inflows in gold and currency or, more conveniently, with clearinghouse certificates. These certificates were receipts for banks deposits of gold and legal tender at the clearinghouse.

Clearinghouse loan certificates - In some periods, clearinghouses issued additional certificates called "clearinghouse loan certificates" that could be used to clear checks. These certificates were a commonly used expedient in runs from 1860 until the creation of the Federal Reserve. ${ }^{16}$

The precursor of these loan certificates was an extraordinary issue of clearinghouse certificates in the run on banks in 1857 . Fears about the solvency of banks resulted in a drain of specie and ultimately a run on the banks in New York City in $1857,{ }^{17}$ At this time, banks issued notes that were used as currency, and the banks redeemed them in gold or silver on demand. If a bank failed though, holders of the notes could wind up with less than the promised amount of specie. In 1857, holders of banknotes were concerned about the likelihood that banks in various parts of the country would be able to continue converting their notes into specie at par. As a result of the continuing redemption of their notes, these banks converted their correspondent balances in New York City banks into specie for redeeming their own notes. Thus, specie balances in New York City banks dwindled and this drain of reserves culminated in a run on banks in New York City. On October 13, banks in New York City restricted specie payments, with restriction in many other parts of the United States following.

In part, the effect of this specie drain on banks in New York City was alleviated by a joint agreement of the banks in the New York Clearing House on November 7 . New York state banks that were not redeeming their notes agreed to pay 6 percent interest on them, and the clearinghouse agreed that the notes of the

16This section owes much to the analyses in Timberlake

(1984) and Gorton (1985b).

(1931), pp. 97-99, 141-44; Calomiris and Schweikart

(1988), pp. $31-56$. 
banks could be used as backing for clearinghouse certificates. Until they were gradually retired, these certificates were used for clearing checks just as if they were clearinghouse certificates backed by deposits of specie.

Clearinghouse loan certificates were first issued in 1860. In anticipation of war, Southerners converted their deposit balances in Northern banks into specie and, just as in 1857, banks in New York City were confronted with a drain of their specie reserves ${ }^{18}$ After the election of Abraham Lincoln in November, the banks in the New York Clearing House responded to the drain by jointly agreeing to allow bonds issued by the federal government and the state of New York to be used as backing for certificates, called "clearinghouse loan certificates," which could be used for clearing checks.

The procedure adopted in 1860 was basically the same as in every later instance when such certificates were issued. A loan committee was established which examined collateral and issued certificates based on the collateral. Upon using a loan certificate, a bank was required to pay interest, at a rate fixed by the clearinghouse, to any bank that held its loan certificates. ${ }^{19}$ The members of the clearinghouse, however, were jointly liable for any loss attendant on holding a loan certificate. In addition, the clearinghouse agreements specified a date at which loan certificates would no longer be acceptable for settling balances at the clearinghouse.

Several features of the practices of clearinghouses indicate that, in issuing loan certificates, members of a clearinghouse were pooling their resources to deal with a common problem of withdrawals. Clearinghouse members pledged to absorb any losses on loan certificates as a group, with losses allocated according to each bank's capital. Losses were not likely, however, because the borrowing banks pledged assets with the clearinghouse, receiving loan certificates for a fraction of the value of the assets. In some panics, clearinghouse members stopped the weekly publication of their individ-

19Swanson (1908) provides a detailed account of this episode.

19The annual rates were 7 percent in 1860 and 1873 and 6 percent in every other instance when they were issued. Comptroller of the Currency (1915, vol. 1), p. 103.

2oMembers of the New York City Clearing House agreed to pool reserves in the panic of 1873 but not in the following ual balance sheets and published combined balance sheets of their members, thus withholding information on the relative weakness of individual members. ${ }^{20}$

Clearinghouse loan certificates were created several times in the 55 years from 1860 to 1914. Table 4 shows the dates when these certificates were issued by the New York Clearing House. ${ }^{21}$ As a quick comparison of tables 3 and 4 shows, clearinghouse loan certificates were issued whenever convertibility of deposits into currency was restricted. This is no coincidence, because clearinghouse loan certificates were an important part of banks' strategy for staying open after a run on the banking system.

Although first issued in 1860 in New York City only, the use of clearinghouse loan certificates became widespread over time (Stevens 1894; Andrew 1908; Cannon 1910). In 1873, the clearinghouses in New York City, Boston, Cincinnati, New Orleans, Philadelphia and St. Louis issued them. In 1884, New York City again was the only clearinghouse to issue loan certificates, but in 1890 it was joined by Boston and Philadelphia. In 1893, clearinghouses in at least 12 cities issued loan certificates, and in 1907, banks in 42 of 145 cities in the United States with more than 25,000 people used such certificates.

Loan certificates and restrictions - Even with access to clearinghouse loan certificates, banks could provide currency in a run only until they exhausted their inventories of specie and legal tender, ${ }^{2 z}$ During restrictions, banks rationed currency, meeting the requests by some customers for their customary withdrawals of currency and denying requests by others. Banks that were members of the clearinghouse continued to accept checks drawn on other clearinghouse members when deposited by their customers. As a result, depositors could make payments by writing checks drawn on their accounts or with certified checks issued by their banks. The major limitation was that the checks generally could not be exchanged for specie or currency by the recipient of the check.

panics. Sprague (1910), pp. 46, 120; Myers (1931), pp $408-20$.

21The New York Clearing House authorized but did not issue loan certificates in December 1895 and Augusi 1896. Gorton (1985b), p. 280 , in. 11 .

22This section draws heavily on Sprague (1910). 
Table 4

\section{Clearinghouse Loan Certificates Issued by the New York City Clearing House: Dates, Duration and Magnitudes (dollar amounts in millions)}

\begin{tabular}{|c|c|c|c|c|}
\hline Year & Date first issued & honihs untl & Maximum amount & Deposits \\
\hline 1860 & November 23 & 3112 & 5. 6.9 & 996 \\
\hline 1861 & Septenber 19 & 7114 & 22.0 & 99.3 \\
\hline 1863 & Novernber 6 & 2314 & 96 & 159.5 \\
\hline 1864 & March $?$ & 3.14 & 16.4 & 1680 \\
\hline 1873 & Seplenber 2 ? & $33 / 4$ & 224 & 1748 \\
\hline 1884 & maylls. & $4 \sqrt{14}$ & 279 & 3172 \\
\hline 1890 & Novenber 12 & $23 / 4$ & 152 & 886.5 \\
\hline 1898 & Wre 21 & 420 & 38,3 & 398,0 \\
\hline 1007 & October 26 & 5. & 88.4 & 10237 \\
\hline 1916 & Algust 3 & $y$ & 1092 & \\
\hline
\end{tabular}

Sources see data appendlx available on request.

If a check was not deposited at the issuing bank but at another bank in the local clearinghouse, the issuing bank could obtain more loan certificates to settle with the bank that accepted the check. If the check was deposited at a bank in another area, the receiving bank could deposit the certified check with a correspondent in the clearinghouse of the issuing bank.

Initially, these certificates were used only as a means of payment by other members of the clearinghouse, but in later years, they also were used as currency. ${ }^{23}$ In 1893 , clearinghouse loan certificates were issued in small denominations by some clearinghouses as a substitute for currency, In addition, banks in several cities with no clearinghouse issued notes that were jointly guaranteed by the banks in the cities. In 1907, banks in many parts of the country created loan certificates which temporarily were used as currency, In 53 of the 71 larger cities in which banks jointly created loan certificates, banks issued the certificates to the public as currency. These issues of currency, which were extra-legal, were given legal status by the AldrichVreeland Act, which permitted associations of national banks to issue temporary currency. National banks used that privilege in 1914.

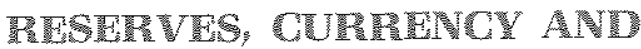 WONEV}

\section{Natio of Teserves to Deposits}

Clearinghouse loan certificates were at least a partial remedy for runs on the banking system because, with access to them, banks could operate with relatively low reserve ratios. ${ }^{24}$ Figure 2 shows the reserve ratios for banks in New York City weekly from 1853 through 1909. The vertical lines in the figure indicate the first week when the extraordinary certificates of 1857 or clearinghouse loan certificates were issued. As one can see, the reserve ratios generally drop around the dates when the New York clearinghouse issued loan certificates, reflecting the effects of bank runs. During several periods when they used loan certificates to cover adverse clearings among themselves, the reserves of banks in New York City fell below required levels (25 percent of deposits after 1874) for at least a short period.
23Andrew (1908) and Cannon (1910), pp. 107-112, ch. XI, discuss this aspect of clearinghouse loan certificates. Slevens (1894), pp. $145 \cdot 48$, provides some information for 1893 based on contemporary correspondence. Timberlake (1981) discusses the significance of private money in nonpanic periods.
${ }_{24}$ t also was possible for the banks to create sufficient loan certificates that interest-earning assets as well as deposits expanded. According to some authors [Cannon (1910), pp. 75-136; Sprague (1910), pp. 45-46, 1711, one of the objectives of clearinghouses in authorizing loan certificates was to expand loans by clearinghouse members. 
In 1873,1893 and 1907 , the banks in the New York City clearinghouse restricted convertibility shortly after they had begun borrowing clearinghouse loan certificates. The reserve ratio rose sharply after the banks restricted payments, and they built up substantial excess reserve positions before resuming payments to depositors. The New York City banks also built up their excess reserves substantially after they created these certificates in 1860 and 1884, and after the creation of the extraordinary certificates of 1857 .

The decreases in reserve ratios at the time of runs were short-lived. Indeed, the quarterly data in figure 3 for all banks in the United States from 1853 to 1935 do not show these sharp declines in the reserve ratio. They do show, though, the increases in the ratio after banks restricted convertibility.

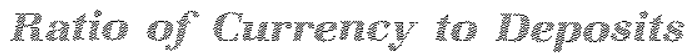

We would expect a rise in the ratio of nonbank money held by the nonbank public to bank money in a run on the banking system, at least until banks limited the reserve outflow by restricting payments. The year-end data for 1856 and 1857 show some indication of an effect of withdrawals in the panic of 1857 , which occurred in the fall of that year. The ratio of specie held by the public relative to bank notes and deposits rose from 47 percent in December 1856 to 57 percent in December 1857. Figure 4 shows these data and quarterly data on the currency-to-deposit ratio for the U.S. banking system from 1867 to 1935 . This ratio generally increases around the dates when banks in New York City issued clearinghouse loan certificates or restricted currency payments.

The most extreme rise in the currency ratio in figure 4 occurs in the early 1930s. Friedman and Schwartz (1963) argue that the rise in the currency ratio was more extreme in the early 1930s than before the operation of the Federal Reserve System because, rather than restricting currency payments, the banks expected the Fed to provide reserves. In the event the Federal Reserve failed to provide sufficient reserves. ${ }^{25}$

\section{Mrom}

As the example in table 2 illustrates, a bank run results in a decrease in the money stock for a given monetary base. Table 5 shows the quarters with relatively large decreases in the money stock from 1867 to 1935 and zero or positive growth of the monetary base. Every quarter with a decrease in the money stock at greater than a 2 percent annual rate and nonnegative growth of the monetary base is included in the table.

Of the six periods in table 5 , only one -1877 to 1878 - is not associated with a restriction of convertibility or the creation of clearinghouse loan certificates in New York City. The decreases in the money supply in 1877 and 1878 occur during the Treasury's retirement of greenbacks prior to resumption of dollar convertibility into gold on January 1, 1879. ${ }^{26}$ All of the dates of general restriction $-1873,1893$, 1907 and 1933 - are periods in which the money stock fell and the base increased for at least one quarter. The year 1884 has some characteristics of bank runs: banks in New York City created clearinghouse loan certificates, but conversion of deposits into currency was not restricted. As the table indicates, the highest rates of decrease in the money stock occurred from 1931 to 1933, after the Federal Reserve was established.

\section{PPECWTS OP TANK RUNG}

While the previous section presents evidence that there were several episodes of runs on the U.S. banking system before the Federal Reserve was formed, it provides little indication of the importance of their effects. 'This section provides some perspective on the impact of those runs.

\section{Lasies Dy Deposilars}

The premiums on currency provide one measure of the cost of runs to bank depositors. In terms of currency, depositors suffered a loss on their deposits during these periods. The premiums indicate that, immediately after runs on the banking system, some people were willing to exchange currency for certified checks at 96 cents or more on the dollar and, within a

\footnotetext{
25See Friedman and Schwartz (1963), pp, 167-72, 308-12.

26Friedman and Schwartz (1963), ch. 2, discuss this period in detail. They attribute these movements to runs on barks
}

outside New York City. Friedman and Schwartz (1963), pp. $56-58,82$. 


\section{Figure 2}

\section{Reserve Ratio}

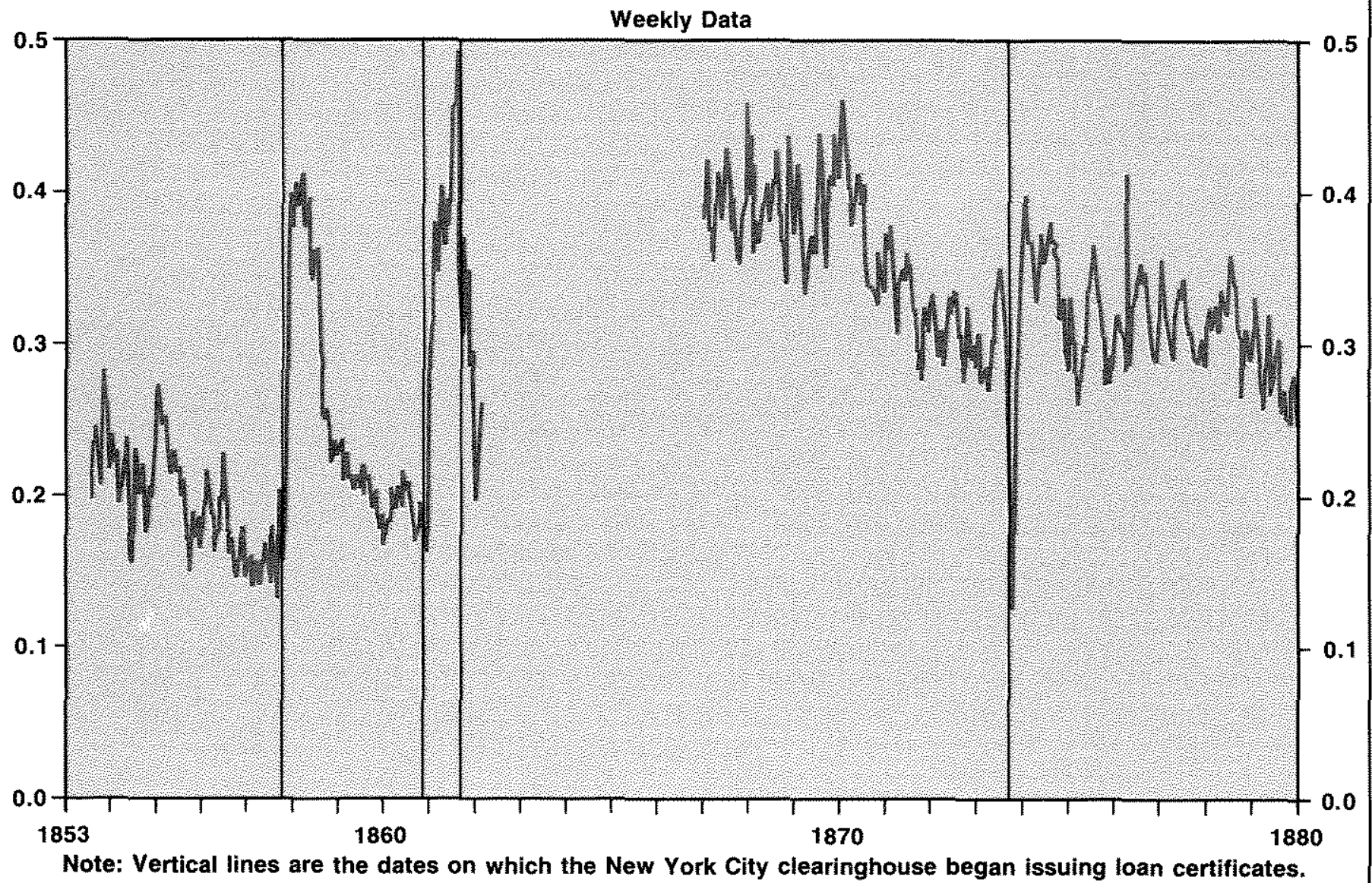

month, the currency premiums were less than 2 percent. $^{27}$

Depositors also suffered losses when banks closed. The total losses borne by depositors in closed banks from 1865 through 1933 were at an annual rate of 21 percent of total deposits. Before the Great Depression, the general trend of these loss rates was downward. The loss rates were .19 percent in $1865-80, .12$ percent in $1881-1900, .04$ percent in $1901-20$, and rose to a peak of .34 percent in $1921-33$.

These figures are for all years and understate the loss rates in years with runs. Depositors' losses on total deposits exceed .25 percent in 12 years: $1873,1875-78,1884,1891,1893$ and
1930-33. The average loss rate in these 12 years is .78 percent of total deposits. In all but two of these periods, either convertibility of deposits was restricted or clearinghouse loan certificates were issued in New York City. In only one year was convertibility of deposits into currency restricted, loan certificates issued, and the loss rate less than .25 percent: 1907.28

In the 1930s, for which data on individual years are available, it is possible to get reason" ably accurate estimates of loss rates borne by the depositors in closed banks. The losses were not bome evenly across the population: an average loss rate per dollar of total deposits of .47 percent of total deposits in 1930 does not
${ }^{27}$ It is worth noting that these losses by depositors were counter-balanced at least in part by gains by holders of currency. The bid-ask spread would be a measure of the direct real resource cost of nonpar trades.
28Unfortunately, the data before 1920 are provided only as averages for periods of several years; we know that the loss rates in 1907 and 1908 were not as high as .25 percent, but we do not know more about them. 


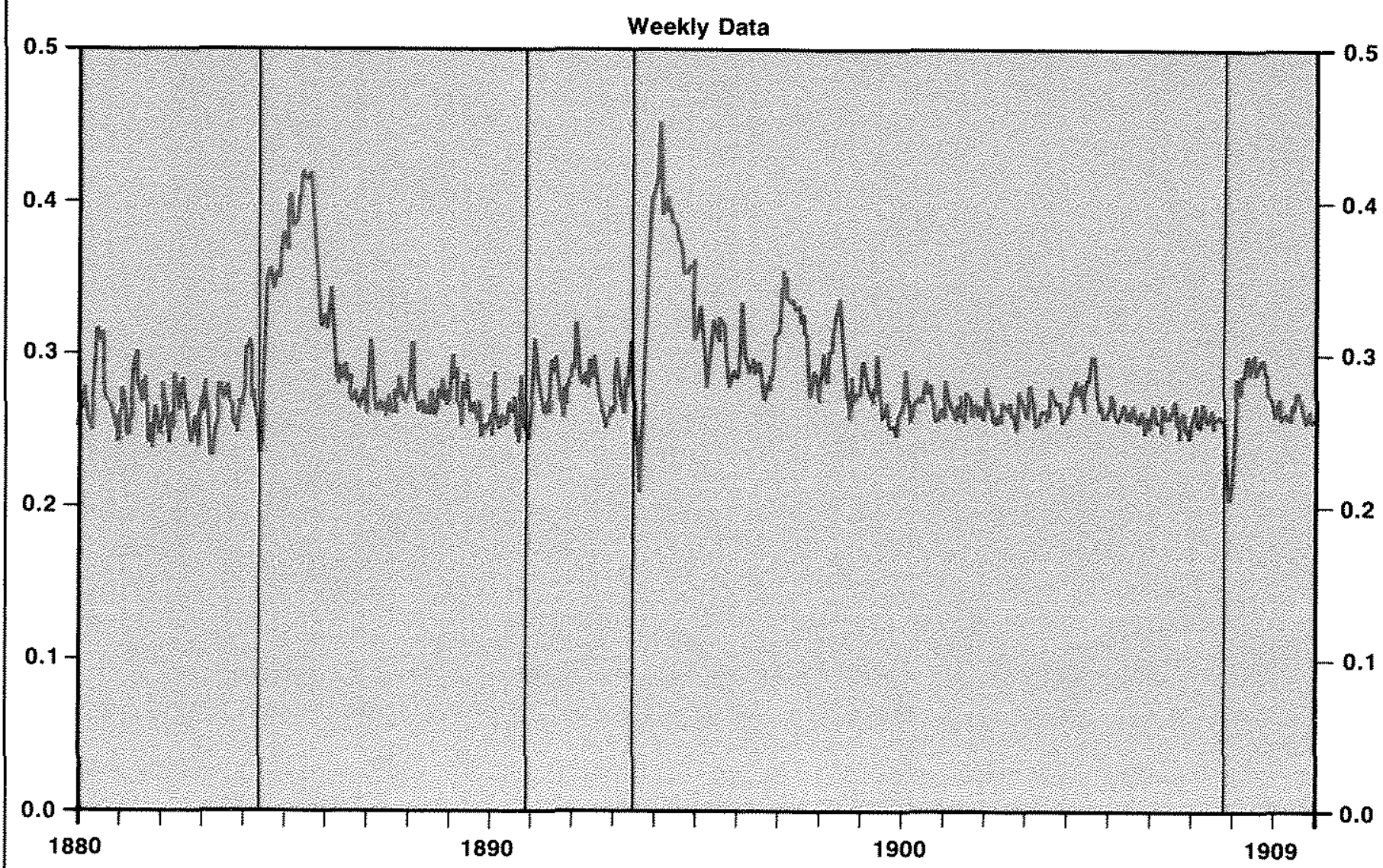

Note: Vertical lines are the dates on which the New York City clearinghouse began issuing loan certificates.

convey the losses borne by individual depositors in individual banks. The average loss rates for depositors in banks that failed are about 28 percent in 1930 and 15 percent in $1933 .^{29}$

In sum, two things seem to be clear from these data. First, some holders of bank liabilities did bear significant losses during periods with runs. These losses were not necessarily caused by the runs themselves. The runs and the losses both may have been triggered by events outside the banking system. It is possible, though, that

29The loss rates in closed banks for every year from 1921 through 1929 are higher than from 1930 to 1933 . This decrease in depositors' loss rate in banks closed in years with runs is not necessarily surprising because runs can force banks to liquidate with positive net worth or net worth less negative than it might be otherwise. This latter observation is consistent with the FDIC's observation that the runs increased the losses from what they might have been under different institutional arrangements.

Second, before the creation of the Federal Reserve, depositors' loss rate from failed banks were declining over time. In this regard, it is worth noting that depositors' loss rate in 1907 was not as high as in as many previous periods, even though the panic of 1907 was the apparent impetus for the creation of the Federal Reserve System. loss rates are less after the 12 "crisis years" than in other non-crisis years. FDIC (1940), pp. 65, 69 .

The loss rates for the national banking period are substantially, but not always, lower than some of the loss rates estimated by King (1983) and Rolnick and Weber (1988) for the earlier free banking period (1838 to 1863). 


\section{Figure 3}

\section{Reserve to Bank Money Ratio}

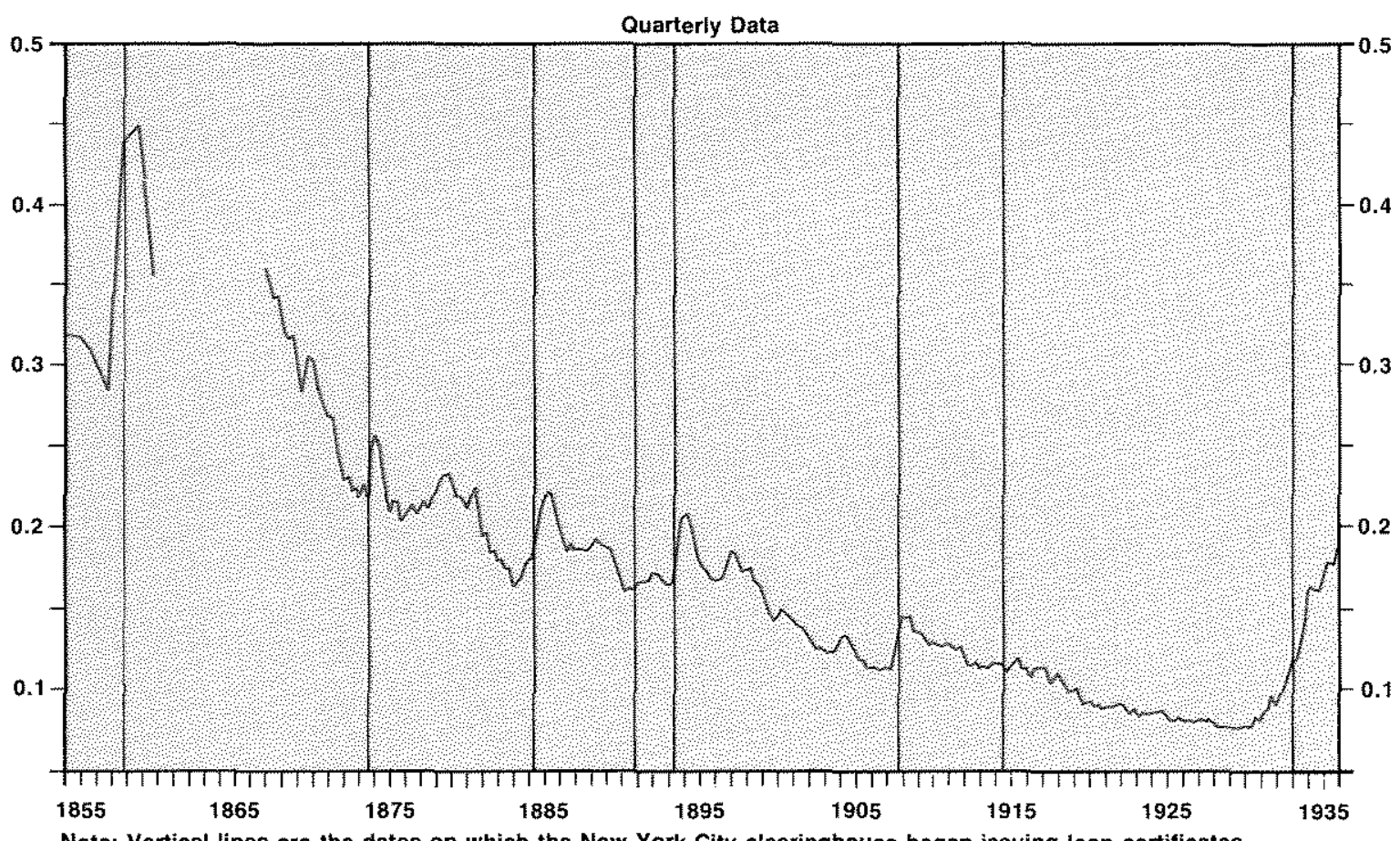

Note: Vertical lines are the dates on which the New York City clearinghouse began issuing loan certificates.

Figure 4

\section{Nonbank Money to Bank Money Ratio}

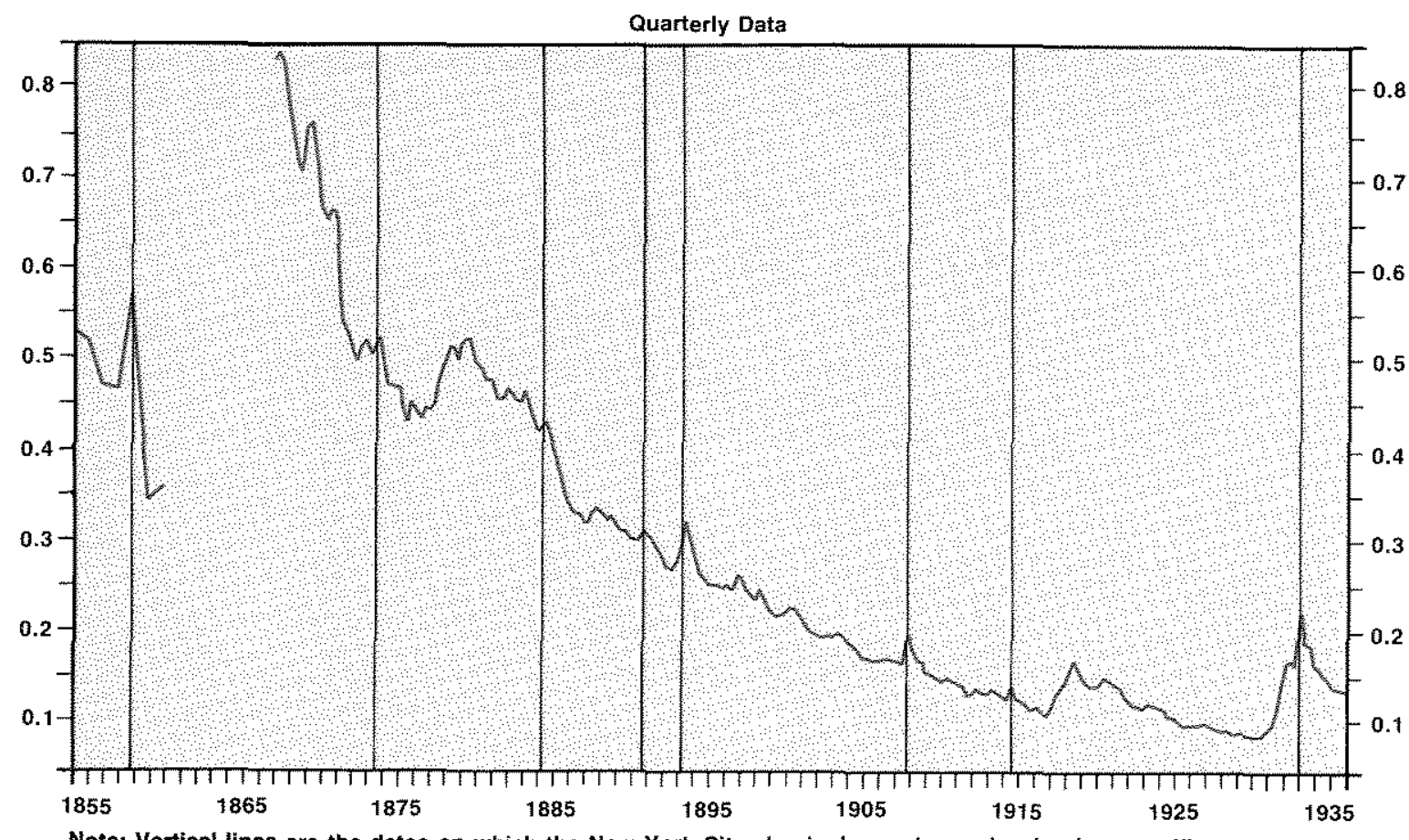

Note: Vertical lines are the dates on which the New York City clearinghouse began issuing loan certificates. 


\section{Table 5}

Growth Rates of the Money Supply and the Monetary Base in Periods in Which the Money Supply Declined at More Than a 2 Percent Annual Rate and the Growth Rate of the Monetary Base was Zero or Positive: 1867 through 1935 (annual growth rates of quarterly data, seasonally adjusted)

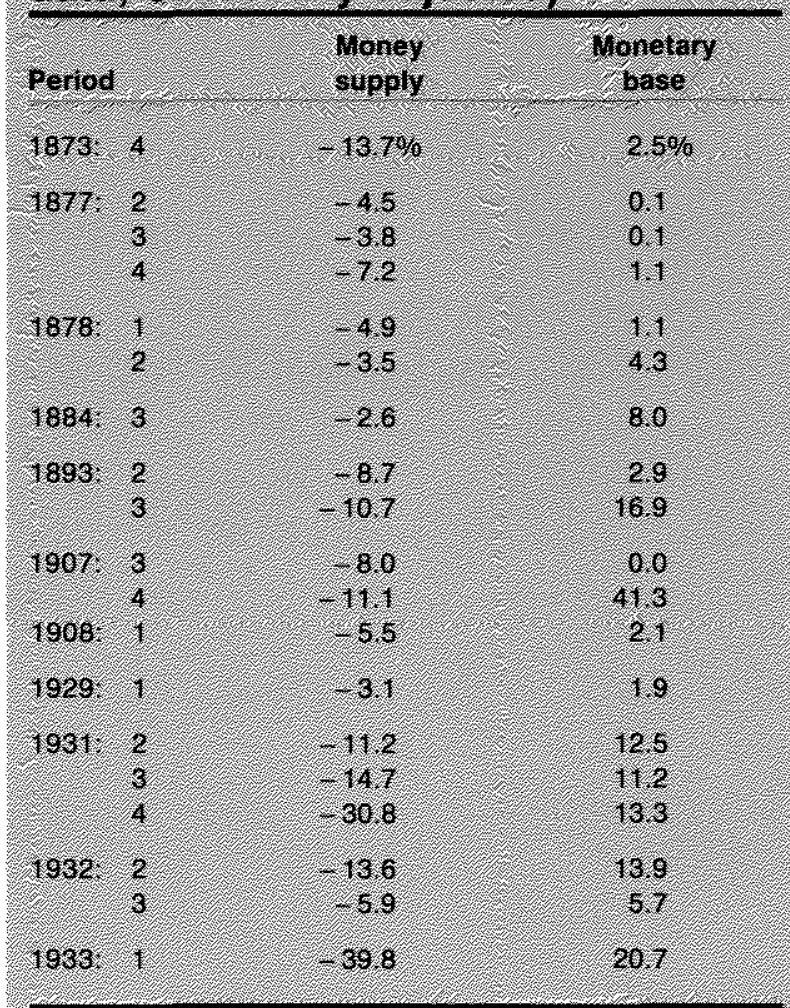

Solices see data appencil available oll requesi.

\section{Losses by Bank Shrmeholders: Bank Fallures}

During restrictions, two things happened. Banks were able to stop the drain of reserves and possibly the sale of assets at distress prices. In addition, they were able to take stock and determine which banks might survive the panic. The importance of this effect perhaps is most clearly indicated by a comparison of llinois and Wisconsin banks just before the Civil War. Banks in Illinois did not restrict specie payments and, ultimately, 93 out of 112 of the banks closed. With similar portfolios of assets, banks in Wisconsin did restrict specie payments and fewer of them, 50 out of 107 banks, ultimately closed. ${ }^{30}$

Another way of getting an idea of the costs to banks is to compare failure rates in banking panics before 1933 with the failure rate in 1933. At the onset of the Depression, banks did not issue clearinghouse loan certificates or restrict currency payments. While the Federal Reserve increased the monetary base, the base was not increased sufficiently to prevent repeated runs until the restriction of payments in the Banking Holiday. As a result, 1933 provides a contrasting indicator of how serious banking panics can be.

Figure 5 shows that banking panics can indeed be associated with relatively large numbers of banks failing. Nonetheless, it is notewor. thy that, before 1933, the only year with restriction and a large increase in the failure rate is $\mathbf{1 8 9 3}$.

\section{Macroeconomic Efectsis}

Figure 6 shows the monthly average call loan rate for 1857 through 1935. Call loans are overnight loans with stock as collateral that are callable without notice. Because call loans were a part of their assets that they were not contractually obligated to continue for longer per. iods, banks in New York City reduced their call loans when they wished to convert part of their assets into reserves. In figure 6 , vertical lines denote the periods when banks in New York City restricted convertibility or had large drains

(1983), Bordo (1986), Gorton (1988), Kaufman (1988), Tallman (1988) and Grossman (1989).
${ }^{30}$ See Dowrie (1913), Krueger (1933) and Economopoulos (1988).

31For other discussions of the macroeconomic effects of bank runs, see Friedman and Schwartz (1963), Bernanke 
Figure 5

Bank Suspension and Failure Rate

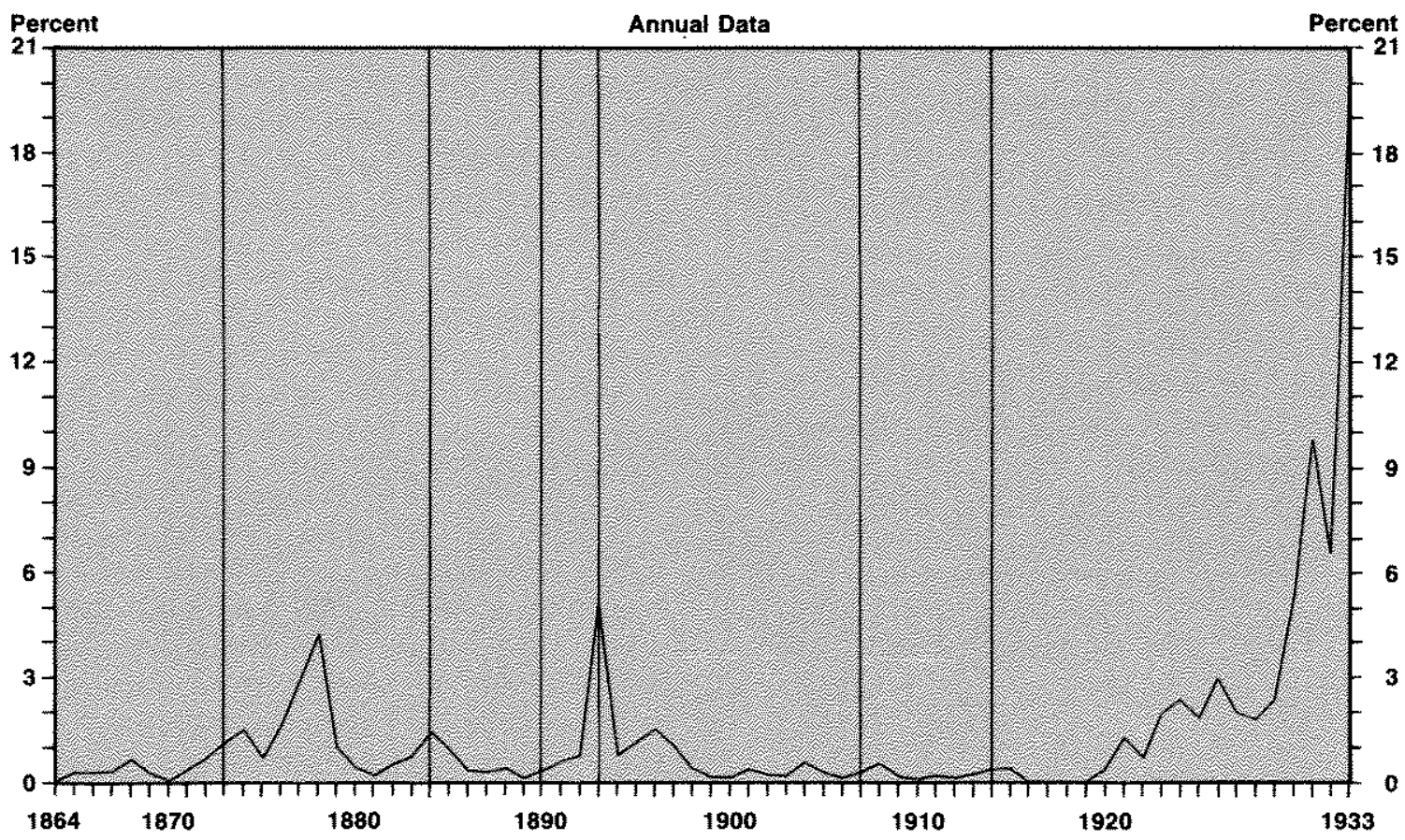

Note: Vertical lines are the dates on which the New York City clearinghouse began Issuing loan certificates.

Figure 6 Call Rate

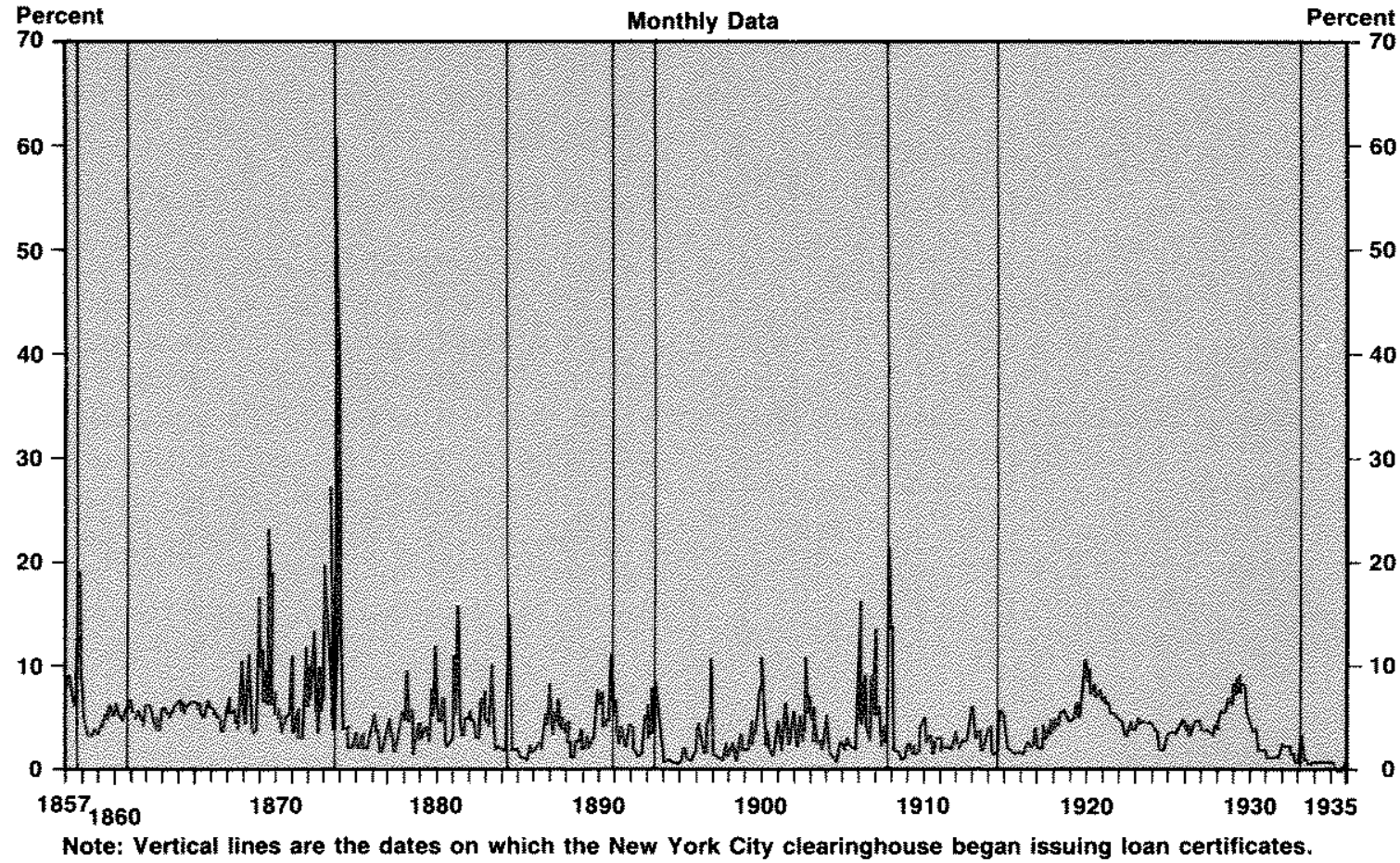




\begin{tabular}{|c|c|c|c|c|}
\hline $\begin{array}{l}\text { Recession } \\
\text { pealc }\end{array}$ & $\begin{array}{l}\text { Recession } \\
\text { trough }\end{array}$ & $\begin{array}{l}\text { Clearinghouse } \\
\text { loan centificottes } \\
\text { issued }\end{array}$ & $\begin{array}{l}\text { Regtriction of } \\
\text { currency payments }\end{array}$ & $\begin{array}{l}\text { Percentage change } \\
\text { in production }\end{array}$ \\
\hline June 1857 & Dec. 1858 & 1 & Oct 1857 & na. \\
\hline 06,1860 & June 1861 & Nov 1060 & & n.2. \\
\hline Aprit 1865 & Poe, 1867 & & & na \\
\hline Ning 1869 & Dec 1870 & & & $2.8 \%$ \\
\hline oct 1873 & Narch 1879 & sept 1873 & Sept. 1873 & -19.3 \\
\hline March 1882 & Nay 1885 & May 1684 & & -13.7 \\
\hline Naret 1887 & Apri, 18:8 & & & -9.2 \\
\hline July 1890 & Nay 1891 & Nov 1890 & & 29.2 \\
\hline Jan 1893 & Sune 1894 & Ine 1998 & Avg 1893 & 549 \\
\hline Dec. 1895 & Jine 1897 & & & -21.9 \\
\hline June 189 . & Dee. 1900 & & & -6.7 \\
\hline Sept. 1902 & Aug 1904 & & & 200 \\
\hline May 1907 & Jine 1908 & 0.1 .1907 & Oct 1907 & -50.8 \\
\hline $\operatorname{sen} 1910$ & Jan, 1912 & & & -21.1 \\
\hline Jan 1918 & Dec 1914 & Alig. 1914 & & -458 \\
\hline A4g. 1918 & Mar 1919 & & & -8.8 \\
\hline Jan 1920 & joly 1921 & & & -71.3 \\
\hline May 1923 & aly 1924 & & & -53.8 \\
\hline oct 1926 & Nov 1927 & & & -179 \\
\hline Aug. 1929 & Mar 1930 & & March 1983 & $=866$ \\
\hline
\end{tabular}

I Banks created cerificares backed by bank notes

Sourees. see data apperdix avallable on request.

of reserves to which they responded by issuing clearinghouse loan certificates. While the increases in the call loan rate associated with restrictions and drains are not unique, some are extraordinary.

Evidence that would support the view that bank runs had adverse effects on the economy would be as follows: bank runs occurred just prior to the onset of recessions, and more severe recessions followed banking panics. Table 6 provides information on the timing and severity of recessions and the timing of bank runs. The data do not support a simple conclusion on the macroeconomic effects of bank runs. Other than the episode in 1873 , banks created clearinghouse loan certificates and restricted currency payments several months after the beginning of the recessions. While some of the more severe recessions occurred when banks restricted currency payments, this is consistent with two very different conclusions: restrictions led to severe recessions, or severe recessions led to restrictions.

Table 6 also indicates that several recessions occurred without runs on the banking system. These observations provide information about the stability of the U.S. banking system without a federal safety net. Several recessions, with declines in real output and losses to businesses, occurred apparently without undermining the confidence of the public in the safety of bank deposits to the point of starting runs on the banking system. 


\section{GUNCWUSTEN}

The federal safety net for the banking system includes the Federal Reserve as the lender of last resort, federal deposit insurance, and bank supervision and regulation designed to limit the risk assumed by banks. The rationale for this safety net is that, in its absence, the banking system would be vulnerable to the kind of run on the banking system that occurred in the early 1930 s. The run in the early 1930s, however, was, perhaps, the most extreme run on the banking system in U.S. history.

While several runs on the banking system took place before the formation of the Federal Reserve System in 1914, banks took actions that limited their effects. By issuing clearinghouse loan certificates that other banks accepted to clear checks, banks operated temporarily with relatively low reserve ratios. In the more severe runs, bankers jointly restricted payments but continued operating. Moreover, even prior to the creation of the federal safety net in the United States, runs on the banking system were infrequent. The banking system can operate for many years without runs on the banking system, even in recessions.

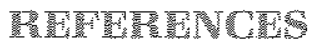

Andrew, A. Piatt. "Substitutes for Cash in the Panic of 1907:" Quarterly Journal of Economics (August 1908), pp. 497-516.

Bernanke, Ben. "Nonmonetary Effects of the Financial Crisis in the Propagation of the Greal Depression," American Economic Review (June 1983), pp. 257-76.

Bordo, Michael D. "Financial Crises, Banking Crises, Stock Market Crashes and the Money Supply: Some International Evidence, 1870-1933," in Forrest Capie and Geoffey $E$. Wood, eds., Financial Crises and the World Banking System (St. Martin's Press, 1986), pp. 190-248.

Calomiris, Charles W, and Larry Schweikart. "Was the South Backward?: North-South Differences in Antebelum Banking during Normalcy and Crisis," unpublished paper, Northwestern University, August 1988.

Cannon, James G. Clearing Houses, U.S. National Monetary Commission, Senate Document No. 491, 61 Cong, 2nd Sess. (U.S. Government Printing Office, 1910).

Comptroller of the Currency. Report (U.S. Department of the Treasury, 1915).

Davis, Andrew M. The Origin of the National Banking System, U.S. National Monetary Commission, Senate Document No. 582, 61 Cong., 2nd Sess. (U.S. Government Printing Office, 1910).
Dewald, William G. "The National Monetary Commission: A Look Back," Journal of Money, Credit and Banking (November 1972), pp. 930-56.

Diamond, Douglas W., and Philp H. Dybvig. "Bank Runs, Deposit Insurance, and Liquidity," Journal of Political Economy (June 1983), pp. 401-19.

Dowrie, George W. The Development of Banking in Minois, 1817-1865. Volume 11, No. 4 of the Series, University of Ilinois Studies in the Social Sciences (University of Illinois, December 1913).

Economopoulos, Andrew J. "Illinois Free Banking Experience," Journal of Money, Credit, and Banking (May 1988), pp. $249-64$.

Federal Deposit Insurance Corporation. Annual Report, (Federal Deposit Insurance Corporation, 1940).

Flood, Robert P., and Peter M. Garber. "Bubbles, Runs, and Gold Monetization," in Paut Wachtel, ed. Crises in the Economic and Financial Structure (Lexington Books, 1982).

Friedman, Milton, and Anna J. Schwartz. A Monetary History of the United States, 1867-1960 (Princeton University Press, 1963).

Gibbons, J.S. The Banks of New York, their Dealers, the Clearing House, and the Panic of 1857. Original publication, 1859. (Reprint edition, Greenwood Press Publishers, 1968).

Gorton, Gary. "Bank Suspension of Convertibility," Journal of Monetary Economics (March 1985a), pp. 177-93.

"Clearinghouses and the Origin of Central Banking in the United States," Journal of Economic Mistory (June 1985b), pp. 277-83.

"Banking Panics and Business Cycles" Oxford Economic Papers (December 1988), pp. 751-81.

Grossman, Richard S. "The Macroeconomic Consequences of Bank Failures Under the National Banking System." U.S. Department of State. Bureau of Economic and Business Affairs, Paanning and Economic Analysis Staff, Working Paper 14, April 1989.

Kaufman, George G. "The Truth About Bank Runs," in Catherine England and Thomas F. Huertas, eds. The Financial Services Revolution: Policy Directions for the Future (Kluwer Academic Publishers, 1988), pp. 9-40.

King, Robert G. "On the Economics of Private Money," Journal of Monetary Economics (July 1983), pp. 127.58.

Krueger, Leonard. History of Commercial Banking in Wisconsin (University of Wisconsin, 1933).

Myers, Margaret G. The New York Money Market, Vol. I, Origins and Development (Columbia University Press, 1931). 
Redlich, Fritz. The Molding of American Banking, 2nd ed. (Johnson Reprint Corporation, 1968).

Rolnick, Arthur d., and Warren E. Weber. "Explaining the Demand for Free Bank Notes," Journal of Monetary Economics (January 1988), pp. 47-71.

Salant, Stephen $W$. "The Vulnerability of Price Stabilization Schemes to Speculative Attack," Journal of Political Economy (February 1983), pp. 1-38.

Schweikart, Larry. Banking in the American South from the Age of Jackson to Reconstruction (Louisiana State University Press, 1987).

Sprague, O. M. W. History of Crises under the National Banking System, U.S. National Monetary Commission, Senate Document No. 538, 61 Cong., 2 Sess. (GPO, 1910).

Stevens, Albert C. "Analysis of the Phenomena of the Panic in the United States in 1893:" Quarterly Journal of Economics (January 1894), pp. 11748, 252-60.

Swanson, William Waker. "The Crisis of 1860 and the First Issue of Clearing-House Certificates," Journal of Political Economy (April 1908), pp. 2†2-26.

Tallman, Ellis. "Some Unanswered Questions about Bank Panics," Federal Reserve Bank of Allanta Economic Review (November/December 1988), pp. 2-21.
Timberlake, Jr, Richard H. The Origins of Central Banking in the United States (Harvard University Press, 1978).

"The Significance of Unaccounted Currencies,"

Journal of Economic History (December 1981), pp. 853-66.

."The Central Banking Role of Clearinghouse

Associations," Journal of Money, Credit and Banking (February 1984), pp. 1-15.

Waldo, Douglas G. "Bank Runs, the Deposit-Currency Ratio and the Interest Rate," Journal of Monetary Economics (May 1985), pp. 269-77.

Wall Street Journal. "Panic Button Finally Triggers Reform, 1907;" February 16, 1989.

Wicker, Elmus. "A Reconsideration of the Causes of the Banking Paric of 1930," Journal of Economic History (September 1980), pp. 571-83. 